\title{
A basic characterization of small-holders' goat production systems in Laghouat area, Algeria
}

\author{
Mourad Laouadi ${ }^{1,2^{*}}$ (D) Safia Tennah ${ }^{2}$, Nacereddine Kafidi ${ }^{2,3}$, Nicolas Antoine-Moussiaux ${ }^{2,4}$ and Nassim Moula ${ }^{2,4}$
}

\begin{abstract}
In order to investigate the practices of goat breeding and establish a classification of goat herds, a survey was conducted with 106 goat breeders in the semi-arid region of Laghouat. Two indigenous breeds were encountered in this survey: the Arabia and the Mekatia; the Arabia being found as the dominant. The results show that breeders choose the breeding goats with a goal of generating more income in cash from the sale of products. The goat milk marketing chain appears to be weak. The milk produced is primary used for home consumption. A multivariate analysis categorized the goat farming of Laghouat region into three groups corresponding to three different farming systems: cluster 1 (pastoral system), cluster 2 (mixed crop-livestock system) and cluster 3 (small herds in zero grazing system). The in-depth study of the goals and contexts of goat farming in Laghouat will allow policy makers to design strategies for sustainable development of goat breeding in the region.
\end{abstract}

Keywords: Goat genetic resources, Farming system, Management, Multivariate analysis, Laghouat, Algeria

\section{Introduction}

The characterization of breeding systems and their diversity is the first step to establish policies for sustainable development of the livestock sector (Ruiz et al. 2008). Animal genetic resources are key in this regard as they are the basis of systems' performance and adaptability. Goat breeding systems across the world are mostly described as low-input systems, whether extensive or semi-intensive (Alexandre et al. 2012; Escareño et al. 2013). The typological approach, using multivariate statistical analysis, offers an important tool to understand the role of goat genetic resources inside this diversity of systems.

Characterized by a great diversity of agro-ecological zones, Algeria is home for many livestock species and breeds. The Algerian goat population is estimated at 4.9 million heads in 2016 (FAOSTAT 2018). A majority of them are raised under low-input farming systems (Madani et al. 2015), mainly in the arid and semi-arid

\footnotetext{
* Correspondence: laouadi.mourad@yahoo.fr

'Department of Agronomy, University Amar Telidji, BP 37G Road of Ghardaïa, 03000 Laghouat, Algeria

${ }^{2}$ Research Laboratory Management of Local Animal Resources, Higher National Veterinary School, El Alia, Oued Smar, 16270 Algiers, Algeria Full list of author information is available at the end of the article
}

areas that extend over $80 \%$ of the territory (Senoussi 2011). This population is composed of native breeds (Arabia, Mekatia, M'zab and dwarf of Kabylia), exotic breeds (Saanen, Alpine, Murcia and Chami) and their crossbreds (FAO 2014). Especially in semi-arid areas as in Laghouat, the study zone of this survey, goats are key in livelihoods of less-endowed households, being a source of cash income, milk and meat (Koeslag et al. 2015). Thanks to their mobile upper lip and higher digestive efficiency for cellulose, goats are enabled to browse a variety of plants not eaten by cattle and sheep; therefore, they are more adapted for survival in harsh environments than other domestic animals (Jansen and van den Burg 2004).

However, despite their vital roles in rural livelihoods, goats have been neglected in development programmes and few studies on goat breeding systems in the Algeria are available.

In this context, the present paper proposes a characterization of goat breeding practices. Thereafter, a typology of herds according to the breeding practices could help future researchers as well as in developing livestock's programmes. 


\section{Study area}

The area of Laghouat is located in southern Algeria, $400 \mathrm{~km}$ from Algiers. It covers an area of $25,052 \mathrm{~km}^{2}$ with a population of 520,188 inhabitants. Its climate is continental in the northwest, with rainfall ranging from 300 to $400 \mathrm{~mm}$. In the centre and the south of the area, the climate is Saharan and arid (rainfall of $150 \mathrm{~mm}$ in the centre and $50 \mathrm{~mm}$ in the south). Winter is characterized by white frosts and summer by heat and sandstorms (Andi 2013). The livestock mainly consists of small ruminants, with about two million sheep and 250,000 goats (DSA 2016).

The study was conducted in seven districts of Laghouat area, as indicated in Figure 1.

\section{Methods}

\section{Data collection}

Individual structured interviews were conducted from March 2014 to May 2015 with 106 small-holders of goats, in the local dialect. The questionnaire included openended and closed questions and covered the following topics: (a) socio-economic characteristics of the household, (b) goat herd composition, (c) purpose of goat keeping, (d) feeding and health management and (e) selection criteria of breeding goats.

\section{Statistical analysis}

All statistical analyses were performed with $\mathrm{R}$ software (version 3.3.1). Besides descriptive statistics, multiple correspondence analysis (MCA) and hierarchical classification analysis (HCA) were performed to establish a typology with the package FactoMineR (Lê et al. 2008). The differences between clusters were tested through chi-square or exact Fisher's test.

Nine variables (Table 1) were chosen, based on the variability of responses gathered and their relevance for characterizing the system and genetic resources' management. The variables pertained to herds' structure (number of goats, presence of Mekatia breed, Arabia breed and crossbreds), the role of goat farming, practices (practice of other agriculture activities, fodder crops and grazing) and mobility of herds (permanent housing, sedentary and seasonal transhumance).

\section{Results}

Socio-economic characteristics

Almost all interviewees were men, with only one woman among 106 respondents. The majority was married $(86.8 \%)$ and either illiterate $(44.3 \%)$ or not exceeding high school level (44.3\%), while only $11.3 \%$ had attended university. The average age was 47.5 years (range 17 to 89 , median 45). Only $13.5 \%$ were below 30 years old. Goat farming was the main activity for only $37.7 \%$ of breeders. The rest kept goats for household's needs (32.1\%) or as a secondary activity (30.2\%).

\section{Goat herd characteristics}

Only $13.2 \%$ of breeders keep exclusively goats (Table 2). For the rest, goats are associated with other livestock species, mainly with sheep $(84.0 \%)$. The number of goats

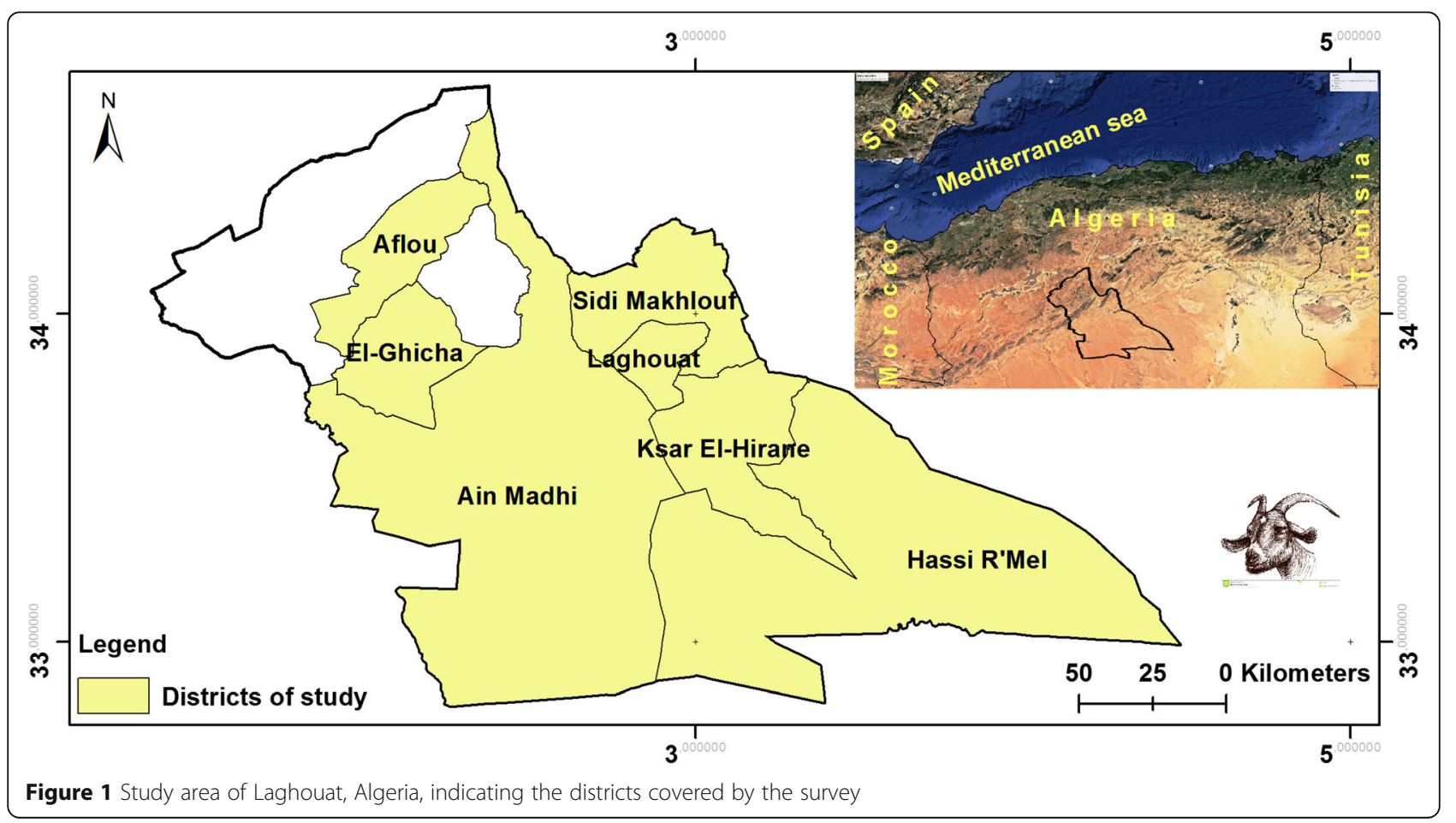


Table 1 Codes for variables and modalities included in the multiple correspondence analysis

\begin{tabular}{|c|c|c|}
\hline Variables & Codes & Modalities \\
\hline \multirow[t]{3}{*}{ Herd size } & \multirow[t]{3}{*}{$\mathrm{HS}$} & Herd $1, \leq 20$ heads \\
\hline & & Herd2, 21 to 40 heads \\
\hline & & Herd $3,>40$ heads \\
\hline \multirow[t]{3}{*}{ Herd mobility } & \multirow[t]{3}{*}{ Mob } & Mob0: permanent housing \\
\hline & & Mob1: sedentary \\
\hline & & $\begin{array}{l}\text { Mob2: seasonal } \\
\text { transhumance }\end{array}$ \\
\hline \multirow{3}{*}{$\begin{array}{l}\text { Role of goat farming in the } \\
\text { household }\end{array}$} & \multirow[t]{3}{*}{ RGFarm } & Farm1: family activity \\
\hline & & $\begin{array}{l}\text { Farm2: principal economic } \\
\text { activity }\end{array}$ \\
\hline & & $\begin{array}{l}\text { Farm3: secondary economic } \\
\text { activity }\end{array}$ \\
\hline \multirow[t]{2}{*}{ Mekatia breeding } & \multirow[t]{2}{*}{ MKB } & MKO: no \\
\hline & & MK1: yes \\
\hline \multirow[t]{2}{*}{ Arabia breeding } & \multirow[t]{2}{*}{ ARB } & ARO: no \\
\hline & & AR1: yes \\
\hline \multirow[t]{2}{*}{ Crossbred breeding } & \multirow[t]{2}{*}{$\mathrm{CXB}$} & CxO: no \\
\hline & & CX1: yes \\
\hline \multirow{2}{*}{$\begin{array}{l}\text { Practice of other agricultural } \\
\text { activities }\end{array}$} & \multirow[t]{2}{*}{$\mathrm{AA}$} & AA0: no \\
\hline & & AA1: yes \\
\hline \multirow[t]{2}{*}{ Practice of forage crops } & \multirow[t]{2}{*}{ ForP } & For0: no \\
\hline & & For1: yes \\
\hline \multirow[t]{2}{*}{ Practice of grazing } & \multirow[t]{2}{*}{ Pat } & Pat0: no \\
\hline & & Pat1: yes \\
\hline
\end{tabular}

Table 2 Goat herds composition in Laghouat region

\begin{tabular}{lll}
\hline Variables & Modalities & Frequencies (\%) \\
\hline Specialization of livestock & Specialized in goat & 13.2 \\
& Mixed species & 86.8 \\
Native breeds & Mekatia & 45.3 \\
& Arabia & 6.2 \\
Ather breeds & Arabia and Mekatia & 4.6 \\
& & 54.7 \\
& Crossbreds & 15.5 \\
& Saanen & 10.4 \\
& Arabia and Saanen & 1.7 \\
& Crossbreds and Saanen & 6.9 \\
& Arabia and Crossbreds & 36.2 \\
& Arabia and Crossbreds and & 24.1 \\
& Saanen \\
& Crossbreds and Saanen and & 5.2 \\
& Alpine
\end{tabular}

per flock varied from 1 to 130 heads, with a median of 17. Almost half $(45.3 \%)$ of breeders keep only native breeds with a predominance of Arabia whereas the other half $(54.7 \%)$ raise various breeds with presence of Saanen and crossbreds in the most cases (Table 2).

There are three management systems: Sedentary: Animals are taken to graze on natural pastures in the vicinity of their farm and thereafter are complemented with conserved fodder or crop residues when they come back to the farm. Permanent housing: Animals are permanently in the farm, they do not go out and receive their necessary food and water in situ. About herd mobility, $63.2 \%$ are sedentary, $21.7 \%$ practise seasonal transhumance during the dry season (May to October) and $15.1 \%$ are in permanent housing.

\section{Purpose of goat keeping and production objective}

The primary reasons cited for goat keeping are obtaining milk and/or meat for home consumption (58.5\%), cash income from selling of goats and kids (57.5\%) and tradition $(45.3 \%)$. However, the main production objective is kids for selling (90.57\%) (Table 3).

\section{Practices \\ Feeding}

The practice of feeding fodder crops was common (64.1\% of farmers), with a predominance of wheat and barley fed. Animals are taken to graze on natural pastures in the vicinity of their farm (84.9\%) and thereafter are complemented with conserved fodder or crop residues. Concentrate feeding is seldom practised (8.49\%).

\section{Health}

Herds are monitored irregularly by a veterinarian or health technician in $82.1 \%$ of cases, and $70.7 \%$ of animals are vaccinated, mainly against enterotoxaemia and brucellosis. The majority of farmers $(82.0 \%)$ practise regular anti-parasitic treatment once (35.6\%), twice (34.2\%), thrice $(7.8 \%)$ or more than four times $(12.3 \%)$ per year. Respiratory (58.1\%) and digestive disorders (46.8\%) are the major diseases that goats usually experience. In case

Table 3 Purpose and production objective of goat farming

\begin{tabular}{lll}
\hline Variables & Modalities & $\begin{array}{l}\text { Frequencies and } \\
\text { citations (\%) }\end{array}$ \\
\hline Reasons for goat keeping & $\begin{array}{l}\text { Milk and/or meat for home } \\
\text { consumption } \\
\text { Cash income }\end{array}$ & 58.5 \\
& Tradition & 57.5 \\
& Passion & 45.3 \\
& Nursing lambs & 15.1 \\
Production objective & Kids & 4.7 \\
& Milk & 90.6 \\
\hline
\end{tabular}


of disease, farmers cited that they treat their sick animals themselves $(67.9 \%)$, call a veterinarian $(74.5 \%)$ or take animals to a veterinarian (59.4\%). Treatments may include medicinal herbs (10.4\%) and other traditional practices $(24.5 \%)$. This knowledge is generally held by elderly people, usually breeders themselves, in the neighbouring areas.

\section{Selection criteria of breeding goats}

The majority of breeders (96.2\%) apply a free mating system, holding bucks in the herd. The replacement animals are sourced either from own flock (40.0\%), from outside $(5.7 \%)$ or from both $(54.3 \%)$.

Criteria for males' and females' selection are summarized in Tables 4 and 5, respectively. All farmers but one had a strategy for male selection against $60.4 \%$ for females. The choice of breeding animals is based on their good body conformation (live weight, large body size) and good performance of parents (high prolificacy, large body size and good milk production) for both males (68.0\%) and females $(54.7 \%)$.

\section{Typology}

Multiple correspondence analysis was applied on nine variables with 21 modalities. On the 106 farm households sampled, two breeders were identified as outliers and not retained for analysis.

The three first factorial components accounted for $55.4 \%$ of total variability (respectively $24.6 \%, 18.3 \%$, and $12.5 \%)$. The variables contributing the most to the first dimension were herd mobility $(24.6 \%)$, practice of grazing (22.9\%), Arabia breeding (17.8\%) and role of goat farming (14.0\%). The main variables contributing to the second dimension were practice of other agricultural activities (31.7\%) and forage cropping (35.1\%). About the third dimension, the variables contributing the most were herd size (34.3\%) and crossbred breeding (28.9\%).

Goat breeders have different aims; a family activity, principal economic or activity or secondary economic activity. For the dimension 1 (Figure 2), the positive coefficients describe herds in permanent housing and breeders considering goat farming as a family activity, while the negative coefficients are attributed to mobile herds, practising grazing and breeders considering goat farming as a main activity. The group of modalities describing mobile herds is

Table 4 Selection criteria for breeding males

\begin{tabular}{ll}
\hline Criteria & Frequencies (\%) \\
\hline Body conformation & 6.8 \\
Performance of ascendants & 4.8 \\
Body conformation and performance of ascendants & 68.0 \\
Other $^{\text {a }}$ & 20.4 \\
\hline
\end{tabular}

${ }^{\mathrm{a}}$ Body conformation + libido + performance of ascendants + good health
Table 5 Selection criteria for breeding females

\begin{tabular}{|c|c|}
\hline Criteria & Frequencies (\%) \\
\hline Body conformation & 3.1 \\
\hline Performance of ascendants & 39.1 \\
\hline Body conformation and performance of ascendants & 54.7 \\
\hline $\begin{array}{l}\text { Body conformation and performance of ascendants } \\
\text { and good health }\end{array}$ & 3.1 \\
\hline
\end{tabular}

associated with the use of Arabia breed, due to their ability for long walking in the steppe.

Dimension 2 (Figure 2) opposes modalities tied to pastoral breeders not having another agricultural activity in addition to livestock (positive coefficients on the axis) to those describe mixed crop-livestock systems, i.e. breeders practising an other agricultural activity such as fodder cropping (negative coefficients on the axis).

Dimension 3 (Figure 3) opposed breeders having small or middle herds keeping crossbreds (positive coefficients on the axis) to those with large flocks owning local breeds (negative coefficients on the axis).

The hierarchical classification led to the description of three clusters (Table 6). The chi-square or exact Fisher's test showed a highly significant difference between clusters $(p<0.001)$ for the majority of variables (practice of agricultural activities other than livestock, fodder cropping, grazing, herd mobility, use of Arabia breed and role of goat farming), a very significant dependence to herd size $(p<0.01)$ and a significant difference between groups about the use of Mekatia breed $\left(p^{<} 0.05\right)$.

Cluster 1 ( $n=29 ; 27.9 \%$ of the total): Pastoral system (Figure 4)

This cluster includes pastoral breeders without other agricultural activity. Pasture in rangelands is their main feed resource. The Arabia breed is present in all of them, for its rusticity and ability to walk for long distances. This cluster included mostly small (44.8\%) or medium (41.4\%) herds. Goat farming is the main activity for more than half of the cluster (58.6\%). Cluster 2 ( $n=60 ; 57.7 \%$ of the total): Mixed croplivestock system (Figure 4 )

This cluster is the largest and includes agropastoralists with mixed crop-livestock activities. Almost all of them cultivate fodder crops (98.3\%), in addition to grazing. This group holds various breeds, with 80.0\% keeping Arabia, 20.0\% Mekatia and 56.7\% crossbreds (between local breeds or local or exotic crossbreeds breeds).

Cluster 3 ( $n=15 ; 14.4 \%$ of the total): Small herds in zero-grazing system (Figure 4)

This cluster includes agro-pastoralists $\mathrm{f}$ the majority (73.3\%), cultivating fodder crops (53.3\%) and keeping goats in permanent housing (100\%). They are small- 


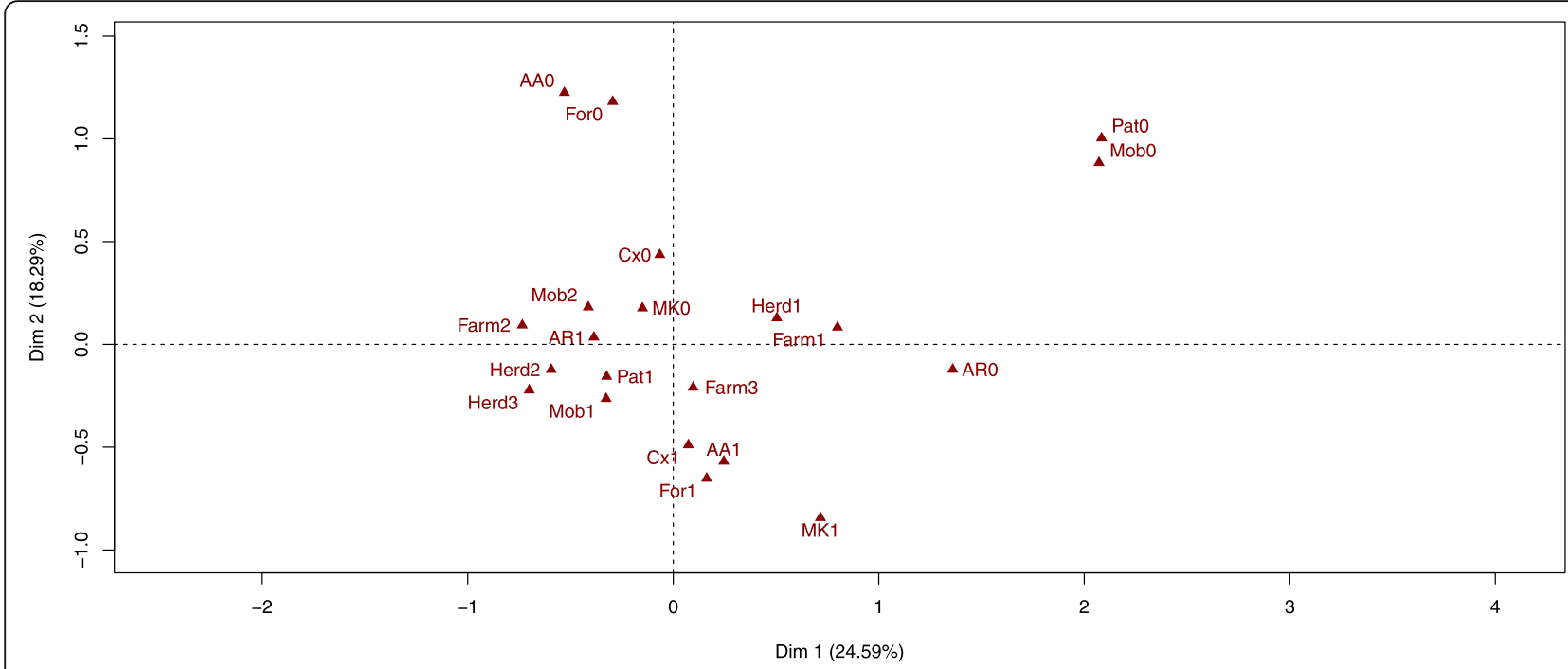

Figure 2 Distribution of modalities on axes 1 and 2 (signification of codes in Table 1)

holders who consider goat farming as a household activity (73.3\%) or secondary activity (26.7\%).

\section{Discussion}

\section{Typology: Overview}

Herd mobility, grazing and feeding practices proved important features for cluster differentiation. Herd size and breeds used were less intensely associated with MCA but necessary to understand different groups formed.

\section{Socio-economic characteristics}

The dominance of men interviewees in the present study is in agreement with that already found by Laoubi et al. (2011) in the same area (94.3\%) and Kadi et al. (2014) in the Kabylian mountainous area in Algeria (86.2\%). This might be due to the traditional and the cultural structure of the society (customs) where men do not let women participate in the interviews during our time in the household.

The proportion of illiterates in this study (44.34\%) was lower than that reported by Hadbaoui (2013) for the semi-arid region of M'sila, Algeria (60\%). The low level of literacy may be partly explained by the remoteness of schools. It results in an inability of farmers to record pedigrees and animal performances.

The low percentage of breeders below 30 years old could indicate that young people are not interested in goat-raising and are moving towards the practice of professions with fast and easy revenue such us business.

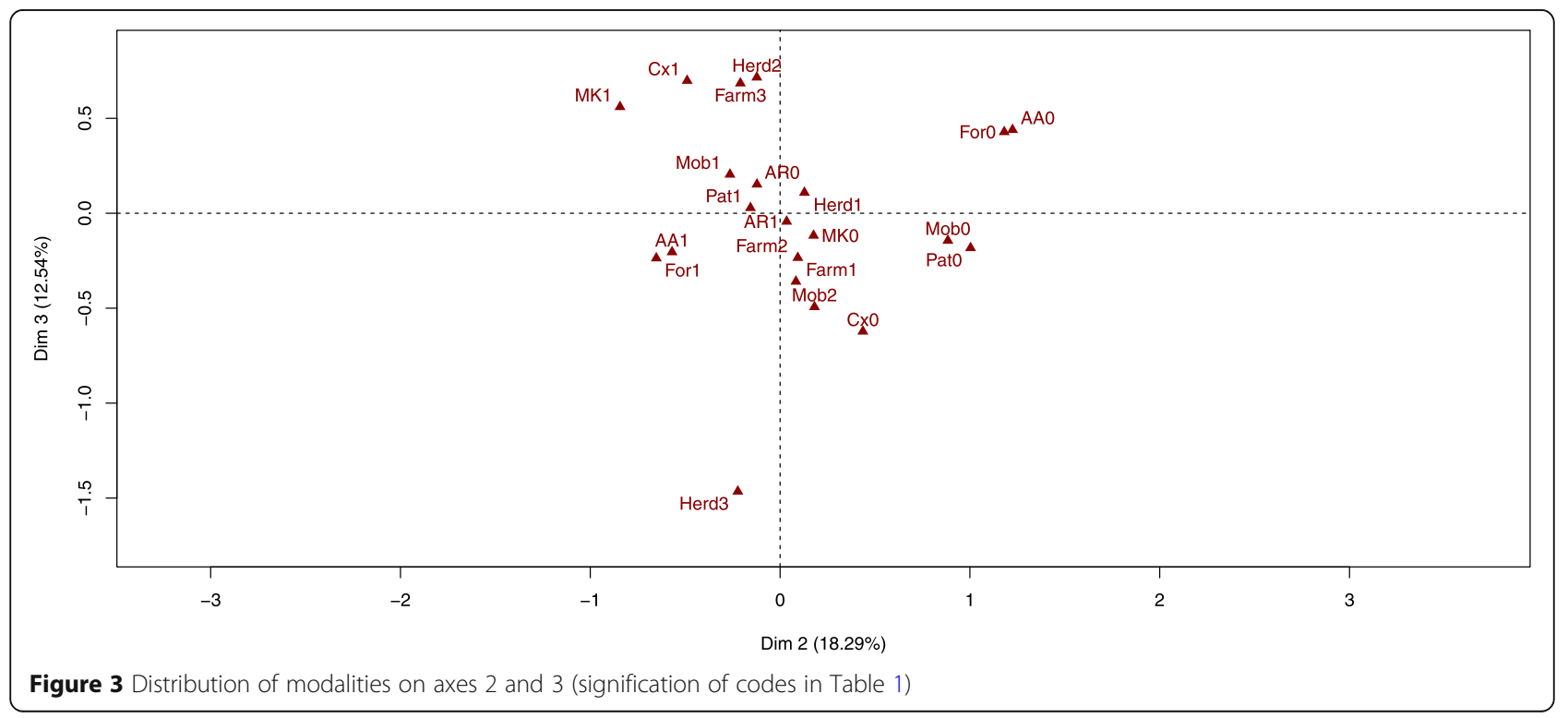


Table 6 Characteristics of farmers in the three clusters by modalities

\begin{tabular}{|c|c|c|c|c|c|}
\hline Modalities & Cluster 1 & Cluster 2 & Cluster 3 & Total & Stat $^{\mathrm{a}}$ \\
\hline Herd1 & 13 & 30 & 15 & 58 & $\overline{* *}$ \\
\hline Herd2 & 12 & 16 & 0 & 28 & \\
\hline Herd3 & 4 & 14 & 0 & 18 & \\
\hline Mob0 & 0 & 0 & 15 & 15 & $* * *$ \\
\hline Mob1 & 20 & 46 & 0 & 66 & \\
\hline Mob2 & 9 & 14 & 0 & 23 & \\
\hline Farm1 & 5 & 17 & 11 & 33 & $* * *$ \\
\hline Farm2 & 17 & 23 & 0 & 40 & \\
\hline Farm3 & 7 & 20 & 4 & 31 & \\
\hline MKO & 28 & 48 & 10 & 86 & * \\
\hline MK1 & 1 & 12 & 5 & 18 & \\
\hline ARO & 0 & 12 & 11 & 23 & $* * *$ \\
\hline AR1 & 29 & 48 & 4 & 81 & \\
\hline $\mathrm{CxO}$ & 19 & 26 & 10 & 55 & ns \\
\hline$C \times 1$ & 10 & 34 & 5 & 49 & \\
\hline AAO & 29 & 0 & 4 & 33 & $* * *$ \\
\hline AA1 & 0 & 60 & 11 & 71 & \\
\hline ForO & 29 & 1 & 7 & 37 & $* * *$ \\
\hline For1 & 0 & 59 & 8 & 67 & \\
\hline Pat0 & 0 & 0 & 15 & 15 & $* * *$ \\
\hline Pat1 & 29 & 60 & 0 & 89 & \\
\hline
\end{tabular}

Stat ${ }^{a}$ statistical significance of the chi-square or exact Fisher's test for differences between clusters, $n s$ not significant

${ }^{*} p<0.05 ;{ }^{* *} p<0.01 ;{ }^{* * *} p<0.001$

\section{Goat herd characteristics}

The highly common association of sheep with goats was previously reported in Algeria, in Chemini region (Moula et al. 2017). The proportion of goats compared to sheep in this study was $17.02 \%$ in favour of sheep. Traditionally, sheep meat is the most appreciated by the North African population, linked to its cultural importance, being central to religious and family ceremonies. In Algerian rural areas, goats are generally used to supply household's daily needs in milk and meat, while sheep meat is more expensive, therefore kept for sale or important ceremonies.
Almost half of herds were strictly composed of indigenous breeds, with a predominance of Arabia. This survey pointed to the strong link between the Arabia breed and steppe pastoralism (cluster 1) but also its dominant in mixed crop-livestock systems. According to our survey, breeders appreciate this breed for its low requirements, its resistance to harsh climatic conditions and its ability to walk long distances, compared to other breeds (Mekatia, Saanen and Alpine).

The strong presence of Saanen and crossbreds (the latter present in all clusters) in the other half of the sample indicates the interest of farmers for productive features like milk production and quality of meat.

Breeders interviewed in the survey describe the Mekatia breed as a good dairy breed. It is weakly present in general, with a higher importance in the zero-grazing systems where it is present in a third of the sample. Suited to more intensive conditions, this breed is now threatened by local constraints to development of a profitable goat milk value chain, contrasting with the more appealing business of Arabia and crossbred herding. Goat owners contribute to the evolution and conservation of these breeds according their goals (cash income) and practice uncontrolled crossbreeding with mainly Arabia and other breeds (local or exotic).

Herd mobility in the present sample is typical of the semi-arid region with a predominance of extensive grazing, as also shown in M'sila (Algeria) by Hadbaoui (2013). However, this extensive grazing is often practised within a sedentary way of life that is an increasing trend in the region, linked to land privatization and schooling of children (Deleule 2016). Goat owners in this study also mentioned insecurity in the region as a motive for sedentarisation. According to Rondia (2006), the sedentarisation leads to a weakening of the past collective management institutions, giving way to an uncoordinated use of natural resources and a degradation of lands. From the perspective of animal genetic resources, both trends, i.e. sedentarisation and land degradation, lead to new needs that will drive goat breed evolution in the zone. Based on the present dominance of Arabia and exotic crossbreds, these evolutions could result in a

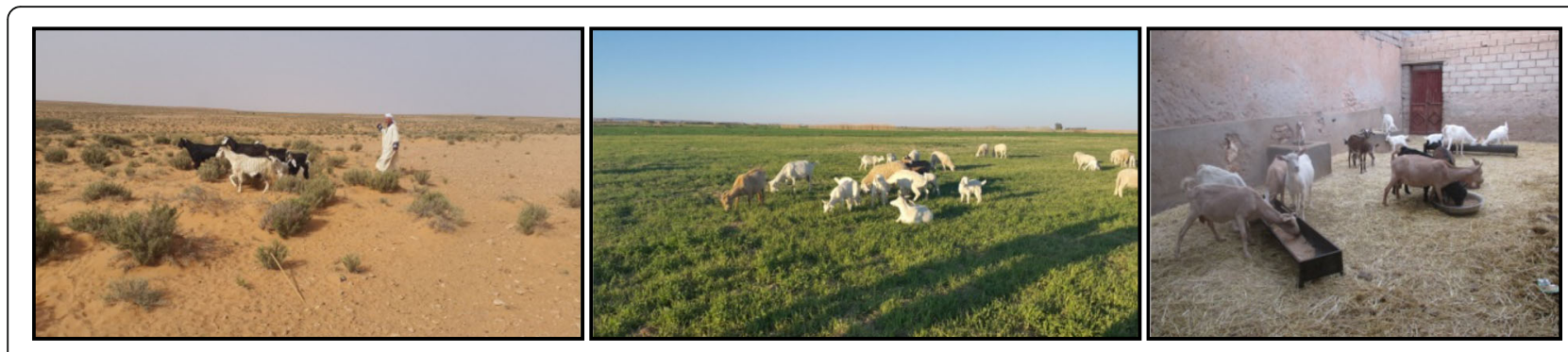

Figure 4 Different production systems. Left: pastoral system. Middle: mixed crop-livestock system. Right: zero-grazing system (personal photographs) 
neglect of the Mekatia breed. A cautious surveillance of their number is necessary together with conservation actions. In situ conservation could be considered in this regard, based on its reported productive abilities, which therefore need to be thoroughly assessed, provided that interesting markets can be promoted for this product.

\section{Purpose of goat keeping and objective of production}

Knowledge of reasons for keeping animals is a prerequisite for deriving operational breeding goals (Jaitner et al. 2001). In the study area, the primary motives for goat keeping are in agreement with those found in Maghreb countries (Ammar et al. 2011; Nassif and El Amiri 2011; Kadi et al. 2014). Goats may be a source of income throughout the year and contribute to the satisfaction of family needs concerning milk and meat.

Gopalakrishnan and Lal (1985) reported that goats generally produce more milk than a cow from the same quantity of nutrients, indicating their more efficient feed conversion. Milk production was not the first objective stated in this survey, not exceeding $10 \%$ of the sample. The low milk production is primarily kept for home consumption and to feed goat kids as the latter represent an important source of income in the zone. On the contrary, goat milk lacks marketing chains in this area. Also, this product (contrary to cow milk) lacks public support policies. Furthermore, to market dairy products, farmers are requested to test milk in laboratories mainly for brucellosis, which constitutes unaffordable costs for these smallholders.

\section{Practices}

The almost generalized free mating system as well as retaining replacement animals from their own herd is expected to increase the level of inbreeding as explained by Kosgey et al. (2006), whereas the selection of replacement animals outside own herds represents a high risk of loss of pure breed.

The criteria chosen by the interviewees for selection of breeding goats (body conformation and performance of parents) are very important, capturing both aspects of productivity (prolificacy) and marketability (kids with good body conformation and coming from good milk producers and prolific mothers will provide more cash income). The selection criteria may differ with breed, herd size, production system and marketing opportunities available in the area (Kebede et al. 2012). In Laghouat area, the purpose of breeders is commercial (production of kids for selling); this is why farmers use body conformation and performance characteristics as their criteria of selection.

\section{Conclusions}

This study provides a working basis for the characterization of goat breeding in Laghouat region. The results highlight that mixed herds (sheep and goats) are common. The management of goats is still traditional. Breeders keep various breeds with predominance of Arabia and crossbreds within a free mating system. The absence of a goat milk marketing chain could lead to the progressive abandonment of the Mekatia breed.

\section{Recommendations}

Policies aiming at the development of these animal genetic resources and systems supporting them should have an economic logic, being profit from performance of the local breeds (resilience of Arabia breed and good milk production of Mekatia breed), changing in habits regarding goat milk marketing and setting up collective schemes to support the sustainable development of goat breeding in Algeria.

\section{Abbreviations}

AA: Agricultural activities; AR0: Arabia 0; AR1: Arabia 1; ARB: Arabia breeding; Cx0: Crossbred 0; CX1: Crossbred 1; CxB: Crossbred breeding; For0: Forage 0; For1: Forage 1; ForP: Forage practice; HCA: Hierarchical classification analysis; HS: Herd size; MCA: Multiple correspondence analysis; MKO: Mekatia 0; MK1: Mekatia 1; MKB: Mekatia breeding; Mob: Mobility; Mob0: Mobility 0; Mob1: Mobility 1; Mob2: Mobility 2; Pat: Pasture; RGFarm: Role of goat farming

Authors' contributions

All authors have reviewed and approved of the final manuscript's submission.

Ethics approval and consent to participate

Not applicable.

Consent for publication

Not applicable.

Competing interests

The authors declare that they have no competing interests.

\section{Publisher's Note}

Springer Nature remains neutral with regard to jurisdictional claims in published maps and institutional affiliations.

\section{Author details}

'Department of Agronomy, University Amar Telidji, BP 37G Road of Ghardaïa, 03000 Laghouat, Algeria. ${ }^{2}$ Research Laboratory Management of Local Animal Resources, Higher National Veterinary School, El Alia, Oued Smar, 16270 Algiers, Algeria. ${ }^{3}$ Canadian Food Inspection Agency, Ottawa, Ontario K1A 0Y9, Canada. ${ }^{4}$ Fundamental and Applied Research for Animals \& Health (FARAH), Sustainable Animal Production, Faculty of Veterinary Medicine, University of Liege, Boulevard de Colonster, 20, building B43, 4000 Liege, Belgium.

Received: 9 March 2018 Accepted: 12 August 2018

Published online: 12 September 2018

\footnotetext{
References

Alexandre, G., R. Arquet, J. Fleury, W. Troupé, M. Boval, H. Archimède, M. Mahieu, and N. Mandonnet. 2012. Systèmes d'élevage caprins en zone tropicale: Analyse des fonctions et des performances. INRA Productions Animales 25 (3): 305-316.

Ammar, H., R. Bodas, M. Ben Younes, and S. López. 2011. Goat breeding systems in the south of Tunisia (Tataouine). In Economic, social and environmental sustainability in sheep and goat production systems. Zaragoza CIHEAM/FAO/ CITADGA. Options Méditerranéennes A100, ed. A. Bernués, Boutonnet JP, I. Casasús, M. Chentouf, D. Gabiña, M. Joy, A. López-Francos, P. Morand-Fehr, and F. Pacheco, 283-288.

Andi (Agence Nationale de Développement de l'Investissement). 2013. Wilaya de Laghouat. http://www.andi.dz/index.php/fr/component/content/article/86guichets-de-l-andi/127-gud-laghouatt. Accessed 20 Sept 2017.
} 
Deleule, M. 2016. Evolution des systèmes d'élevage dans les steppes du Maghreb: Enjeux et perspectives. Mémoire de master 2 GIEBloTE. Canada: Université de Sherbrooke.

DSA (Direction des Services Agricoles). 2016. Statistiques wilaya de Laghouat. Algérie: Ministère de l'Agriculture, du Développement Rural et de la Pèche.

Escareño, L., H. Salinas-Gonzalez, M. Wurzinger, L. Iñiguez, J. Sölkner, and C. MezaHerrera. 2013. Dairy goat production systems: Status quo, perspectives and challenges. Tropical Animal Health and Production 45: 17-34. https://doi.org/ 10.1007/s11250-012-0246-6.

FAO (Food and Agriculture Organization of the United Nations). 2014. Characterization and value addition to local breeds and their products in the Near East and North Africa. In Regional Workshop, Rabat, Morocco, 19-21 November 2012. FAO Animal Production and Health Division de la production et de la santé animales Report No. 3 (Rome), 1-39.

FAOSTAT. 2018. Statistics of Food and Agriculture Organization of the United Nations. http://www.fao.org/faostat/fr/\#data/QA. Accessed 2 Jan 2018.

Gopalakrishnan, C.A., and G.M.M. Lal. 1985. Livestock and poultry enterprises for rural development. New Delhi: Vikas Publishing House.

Hadbaoui, I. 2013. Les parcours steppiques dans la région de M'Sila: Quelle gestion pour quel devenir? Ouargla: Thèse de Magister, Université Kasdi Merbah.

Jaitner, J., J. Sowe, E. Secka-Njie, and L. Dempfle. 2001. Ownership pattern and management practices of small ruminants in the Gambia - implications for a breeding programme. Small Ruminant Research 40: 101-108.

Jansen, C., and K. van den Burg. 2004. L'élevage des chèvres sous les tropiques. Wageningen: Agrodok No.7, Agromisa.

Kadi, S.A., F. Hassani, N. Lounas, and A. Mouhous. 2014. Caractérisation de l'élevage caprin dans la région montagneuse de Kabylie en Algérie. In 8th International Seminar FAO-CIHEAM Network on Sheep and Goats "Technology creation and transfer in small ruminants: Roles of research, development services and farmer associations", ed. M. Chentouf, A. Lopez-Francos, M. Bengoumi, and D. Gabina, 451-456. Tangier: Options Méditerranéennes A108.

Kebede, T., A. Haile, and H. Dadi. 2012. Smallholder goat breeding and flock management practices in the central rift valley of Ethiopia. Tropical Animal Health and Production 44: 999-1006. https://doi.org/10.1007/s11250-011-0033-9.

Koeslag, J., G. den Hertog, and H. Blauw. 2015. L'élevage de chèvres: Conseils pratiques pour les petits éleveurs. Barneveld: Proud Press.

Kosgey, I.S., R.L. Baker, H.M.J. Udo, and J.A.M. Van Arendonk. 2006. Successes and failures of small ruminant breeding programmes in the tropics: A review. Small Ruminant Research 61: 13-28.

Laoubi, K., M. Boudi, M. Adel, and M. Yamao. 2011. Exploring family farm development in dryland agricultural areas: A case study of the Laghouat region of Algeria. African Journal of Agricultural Research 6 (6): 1303-1312. https://doi.org/10.5897/AJAR11.070.

Lê, S., J. Josse, and F. Husson. 2008. FactoMineR: An R package for multivariate analysis. Journal of Statistical Software 25 (1): 1-18. https://doi.org/10.18637/jss.v025.101.

Madani, T., H. Sahraoui, and H. Benmakhlouf. 2015. L'élevage caprin en Algérie: Systèmes d'élevage, performances et mutations. In Workshop national sur "Valorisation des races locales ovines et caprines à faibles effectifs", INRA "Institut National de la Recherche Agronomique d'Algérie", Ministère de l'Agriculture, du Développement Rural et de la Pèche, Alger, Algérie, 2-3 mars 2015. https://drive. google.com/file/d/0Byq7HIXbht6eWGZWdE5ISm1XQzA/view. Accessed 12 Nov 2017.

Moula, N., A. Ait Kaki, L. Touazi, F. Farnir, P. Leroy, and N. Antoine-Moussiaux 2017. Goat breeding in the rural district of Chemini (Algeria). Nature \& Technology 16: 40-48.

Nassif, F., and B. El Amiri. 2011. Promoting multidisciplinary research to improve goat production systems in Morocco. In Economic, social and environmental sustainability in sheep and goat production systems. Zaragoza, CIHEAM/FAO/ CITADGA. Options Méditerranéennes A100, ed. A. Bernués, Boutonnet JP, I. Casasús, M. Chentouf, D. Gabiña, M. Joy, A. López-Francos, P. Morand-Fehr, and F. Pacheco, 299-303.

Rondia, P. 2006. Aperçu de l'élevage ovin en Afrique du Nord. Filière Ovine et Caprine 18: 11-14.

Ruiz, F.A., J.M. Castel, Y. Mena, J. Camúñez, and P. González-Redondo. 2008 Application of technico-economic analysis for characterizing, making diagnoses and improving pastoral dairy goat systems in Andalusia (Spain). Small Ruminant Research 77: 208-220.

Senoussi, A. 2011. Les systèmes pastoraux sahariens en Algérie; quel état pou quel devenir? In Séminaire sur "L'effet du Changement Climatique sur l'élevage et la gestion durable des parcours dans les zones arides et semi-arides du Maghreb". Université Kasdi Merbah, Ouargla, Algérie, 21-24 November 2011.

\section{Submit your manuscript to a SpringerOpen ${ }^{\circ}$ journal and benefit from:}

- Convenient online submission

- Rigorous peer review

- Open access: articles freely available online

High visibility within the field

- Retaining the copyright to your article

Submit your next manuscript at $\boldsymbol{\nabla}$ springeropen.com 